\title{
The Educational Experiences of the Second Generation from Refugee Backgrounds
}

\author{
Authors: Alice Bloch (The University of Manchester) and Shirin Hirsch (University \\ of Wolverhampton)
}

Version accepted for publication by Journal of Ethnic and Migration Studies January 2017

Published version: http://dx.doi.org/10.1080/1369183X.2017.1286972

\begin{abstract}
This paper draws on qualitative interviews to explore the educational experiences amongst the UK born adult children of refugees from Vietnam, Sri Lanka (Tamils) and Turkey (Kurdish). Second generation from refugee backgrounds are characterised by diversity and as a group are increasing numerically. However, little is known about the specificity of their experiences as they have been either subsumed within or have fallen between the research agendas on new migrants, refugees, asylum seekers and the body of research on larger established minorities. This paper sets out to fill a gap in the literature by exploring the perspectives of second generation from refugee backgrounds. We examine the impact of policy - particularly dispersal and mobility on education, the ways in which inter-generational relations and the aspirations of both parents and their children can be shaped by refugee histories, how schools fail to alleviate barriers to parental participation and racism within school settings, especially - though not exclusively - within schools that are less ethnically diverse. We conclude that the policy context and refugee backgrounds shape educational experiences and aspirations but also significant are the structural divisions that reproduce class and race based inequalities.
\end{abstract}

Key words

Second generation, refugees, education, racism, dispersal

This paper focuses on the experiences of education from the perspectives of the UK born adult children of refugees. Education is significant because it holds a central role in ambitions and life course and has been invoked by policy makers, at different times, as an important tool for assimilation, integration, multiculturalism and the promotion of cohesive and inclusive societies (Swann Report 1985; Troyna and Carrington 1990; Cantle 2001; Bloch, Neal and Solomos 2013). Among children who have come to the UK as refugees and asylum seekers, education is also seen as a key site in the promotion of integration (Spicer, 2008). However, education continues to be a setting in which social divisions are maintained and structural inequalities, including those based on race, class and residential patterns, are exacerbated (Tomlinson 2008; Dustmann, Frattini and Lanzara 2012; Alexander, Weekes-Bernard and Chattererji 2015).

Since the 1960s refugees and asylum seekers arriving in the UK have come from diverse regional, ethnic, religious and political backgrounds. Moreover, refugees have different pre- and post-migration experiences, including of persecution and of education and employment (Kushner and Knox 1999). This growing diversity was 
then accompanied in the 1980s by a rapid increase in the numbers seeking asylum. The consequence of refugee and asylum patterns has been a growing number of second generation refugees who have been born in the UK within the context of refugee families with very different social, economic, educational and cultural backgrounds.

In a period of unprecedented human mobility understanding the ways of responding effectively and humanely to the movement of refugees and to their children, born in the context of their parent's exile, is a pressing contemporary policy challenge. However, despite refugee migration patterns and the growing numerical significance of second generation refugees little is actually know about the experiences of this group who are generally subsumed within the broader analyses of second generation from ethnic minority backgrounds within academic literature and policy analysis (Dustmann and Theodoropoulos 2010; Crul, Scheinder and Lelie 2012) This paper fills a gap in the literature by focussing on the experiences of education amongst second generation refugees. It draws out the specificities of different refugee backgrounds and locates these within the education, asylum and refugee policy contexts to illuminate the differing ways in which these intersections can and do effect the experiences of the second generation. Although the paper focuses on the UK case, the findings allow broader insights into the intersections of refugee backgrounds with networks, resources and policy frameworks.

There is a sizeable body of research on race and ethnicity in education that highlights the cleavages between and within groups in relation to outcomes (Department for Education 2014). Differential outcomes are based the intersections of race and racism, class, geography and gender (Rollock et al. 2014; Strand 2014). Additionally, variable access to information about schools (Weekes-Bernard 2007; Bryne and De Tona 2012); teacher racism and stereotyping (Maylor 2015); parental exclusion from or lack of engagement with schools (Crozier and Davies 2007 and the social, cultural and economic resources available to and utilised by parents and families (Vincent et al. 2012; Rollock et al. 2014) are all found to intersect with race and racism and to impact on outcomes.

This paper draws on data collected with second generation people from refugee backgrounds who have spent some or most of their childhoods in London and forms part of a comparative European project. The research examined educational and employment experiences, transnational activities, identity and belonging, community and social networks, family life and the ways in which coming from a refugee background may have shaped their lives. The paper demonstrates the ways in which refugee backgrounds intersect with education both within the family and in relation to school communities and how the pre and post-migration experiences of parents affects their attitudes and aspirations for their children's education, which are in turn transmitted inter-generationally. Also important are the structural divisions within society and school communities (Department for Education, 2014; Rollock et al, 2014).

The paper is in three main sections. First, we provide an overview of the key relevant issues that emerge in the literature in relation to the refugee and asylum context. Secondly, we discus the methods and sampling strategies used. Thirdly we present the data analysis with a focus on: schools attended and parental strategies in relation to education, the intersection of aspirations with refugee backgrounds, the impact of 
policy, including dispersal, on education and parental involvement and school support for active parental engagement.

\section{The asylum context and children as refugees and asylum seekers}

The policy context in place at the time of arrival and settlement for refugees and asylum seekers is relevant to our analysis. Dispersal as a policy was, until the 1999 Immigration and Asylum Act, used as a way of resettling refugee arrivals coming as part of a resettlement programme and this included refugees from Vietnam. Since 2000 dispersal has been integrated into the asylum system and so those arriving as asylum seekers, while waiting for their claim for refugee status to be determined, have largely been dispersed outside of London and sometimes to areas will little history of diversity, inadequate support structures and little understanding among service providers of appropriate service provision (Sales 2007). Mobility is also a function of on-ward migration from dispersal areas and of refugee, asylum and local authority housing policies including the movement of some asylum seekers and refugees out of inner London boroughs (Bloch 2002). In this research, there was a clear pattern of geographical mobility as a consequence of refugee and asylum policy and for some of our interviewees this also resulted in one or more changes of school and feelings of dislocation.

Among the three groups in our study, the first to arrive in the UK were Vietnamese refugees; the first cohort arrived in 1978 from transit camps in Hong Kong. Britain agreed to resettle 10,000 Vietnamese refugees as part of the resettlement programme. Having refugee status on arrival is potentially significant because it takes away the insecurity and limbo of the asylum determination process. On arrival they received some language and orientation classes prior to being dispersed around the UK. Many moved from their dispersal areas to urban centres to alleviate isolation and to access community, support services and employment (Robinson and Hale, 1989). This onward migration also meant that some children, who were born in dispersal areas, had to change schools. Research among Vietnamese refugees found that levels of formal education were low among the refugee cohort and that few had formal skills that could be transferred to the UK economy leading to high levels of unemployment or low skilled jobs (Jones 1983; Somerset 1983).

Refugees from Sri Lanka are predominantly Tamils, seeking refugee status on the basis of their ethnic group having experienced persecution as a minority. Most Tamils, who came as asylum seekers, arrived during the civil war of 1983-2002 but Tamils have also entered the UK as students and on other visas and once in the UK have claimed asylum. The majority of Sri Lankan Tamils live in London and are clustered in certain areas most notably East Ham, in Newham. Estimates place the number of Sri Lankans in the UK at around 100,000 (Cowley-Sathiakumar 2008; Healey 2010). Sri Lanka was a British colony until 1948 and as a consequence many Tamils spoke English on arrival to Britain. Compared to the other two groups in our study, refugees from Sri Lanka were well educated and that, coupled with their greater propensity to speak English, has resulted in transferable skills and for some a movement from unskilled or low skilled work into self-employment.

The third group, Kurds from Turkey, began arriving as spontaneous asylum seekers from the early 1990s as a consequence of political oppression, the lack of economic opportunities, displacement and organised attacks on villages in Eastern Turkey. As asylum seekers, Kurds had to go through the asylum determination process, which 
can result in insecurities while cases are considered and little or no support on arrival (Kushner and Knox 1999; Sales 2007). It is estimated that more than 50,000 Kurds from Turkey have settled in the UK with most living in London (Demir 2012). Many came from rural backgrounds, had few transferable skills and little or no English language on arrival, resulting in low skilled work within co-ethnically owned businesses (Holgate et al. 2012).

These refugee histories will impact on family life, however, refugee children - who are in families rather than unaccompanied minors - have been largely absent in national policy-making (Arnot and Pinson 2005; Taylor and Sidhu 2012). Where interventions have taken place, they are local and piecemeal and tend to be around English language support and trauma rather than providing a more holistic approach that recognises the complexity and diversity of refugee children's needs (Arnot and Pinson 2005; Rutter 2006). While the second generation have been absent in the analysis of refugees, asylum seekers and education, they are not immune to the wider political, media and social attitudes toward immigration and asylum.

Those we interviewed have grown up in the UK at a time when asylum has been high on the policy agenda and has included numerous and increasingly restrictive legislative measures. Between 1993 and 2016 there have been 10 Acts of Parliament relating to immigration and/or asylum. The legislation aimed to curtail access to UK borders; it has reduced in-country welfare provision and support for asylum seekers and largely excluded them from access to the formal and regulated parts of the labour market (Lewis et al. 2015). The 'bogus' versus 'genuine' narrative prevalent when our interviewees were growing up, the anti-asylum rhetoric, constant attacks and hostility by local communities who do not want asylum seekers dispersed into their neighbourhoods and the negative reporting in the mass media will affect experiences (Grillo 2005; Sales 2007; Berry, Garcia-Blanco and Moore 2015). Schools, like other institutions, operate within a climate that is hostile to asylum seekers and migrants (Anderson and Williamson 2004) and so classrooms, playgrounds and school corridors become a critical location for the playing out of relationships between migrant populations and the communities they live in (Reynolds 2008). As countries have different policies, different histories of refugee and asylum migration and variable responses to refugees and migrant communities, focussing on the UK allows for a deeper interrogation into the ways in which aspects of the country case converge to shape experiences.

\section{Methods and sample}

The paper draws on data from 45 in-depth interviews, carried out in 2014 and 2015, with the UK born children of refugees with parents from Vietnam, Sri Lanka (Tamil) and Turkey (Kurds) who spent all or some of their childhoods in London. The three groups offer scope for critical engagement with the complexities between and within different refugee cohorts because they arrived in the UK at different times, under different circumstances and processes and with variable pre and post migration experiences. The different parental backgrounds are central to our analysis as history, resources - both social and economic - immigration status and reception and resettlement polices all impact on the educational experiences and outcomes of children (Portes, Fernández-Kelly and Haller 2009; Rumbaut 2012).

The characteristics of the parents of our interviewees reflected the general premigration characteristics of the three groups. Half of the mothers and fathers of our 
Tamil heritage interviewees had a degree compared with two of the Kurdish parents and none of the Vietnamese parents. Conversely, 13 Vietnamese and 14 Kurdish parents had no education or had been educated up to primary school level compared with 2 of the Sri Lankan Tamil parents. Almost all the parents of those from Vietnamese and Kurdish backgrounds were in low and unskilled work with low income and unsocial hours. There was much greater labour market diversity among the parents of those from Tamil backgrounds and work included legal professionals, health and small business ownership.

Table 1 shows the main characteristics of the sample. Those from Vietnamese backgrounds were the oldest group of interviewees and all but one was working. Reflecting the more recent arrival of Kurds from Turkey, the youngest interviewees were Kurdish with eight out of 14 aged between 18 and 20 and most were students, as were their Tamil heritage counterparts. As we were asking interviewees to recall their experiences of school, the age range does make a difference. Some of those from Kurdish backgrounds had just finished compulsory schooling at the time of their interview and so the memories are recent. For other interviewees the recollections were more retrospective and so memory bias may occur in the data. However, regardless of the timeframes, memories are unreliable (Gardner 2001) and they evolve and become inflected by contemporary life course experiences including class, gender and culture (Sharma 2009; Smart, 2010). In any interview situation, what interviewees choose to share is selected from a repertoire of possible stories. As the research interviewed only the second generation, we rely on their narratives and their perspectives without triangulating with parent and teacher perceptions and experiences. This is not necessarily a limitation; it is the lived experiences of second generation, and the way in which they talk about those experiences, that concerned us.

Table 1: Sample characteristics by parent's country of origin

Base number: 45

\begin{tabular}{|l|c|c|c|c|}
\hline & Vietnam & $\begin{array}{c}\text { Sri } \\
\text { Lanka }\end{array}$ & $\begin{array}{c}\text { Turkey } \\
(\text { Kurds })\end{array}$ & Total \\
\hline Gender & & & & \\
\hline Male & & & & \\
\hline Female & 6 & 9 & 6 & 21 \\
\hline Age & 9 & 7 & 8 & 24 \\
\hline 18 to 20 & & & & \\
\hline 21 to 25 & 0 & 2 & 8 & 10 \\
\hline 26 and over (up to 36) & 1 & 12 & 2 & 15 \\
\hline Main activity & 14 & 2 & 4 & 20 \\
\hline Student & & & & \\
\hline Employed & 0 & 12 & 8 & 20 \\
\hline Unemployed & 14 & 4 & 5 & 23 \\
\hline
\end{tabular}

There is no sampling frame of second generation from refugee backgrounds and so we used snowball sampling from a diverse range of sample starting points that included: gatekeepers from community organisations, through personal networks and networks of colleagues, social media (e.g. Facebook), community activists and local politicians and by snowballing from networks and interviewees. While snowball sampling will include un-measurable sample bias and excludes those outside of the 
networks used as points of referral, we utilised a diverse range of starting points to ensure multiple networks were accessed and in so doing increased the representation of the sample. We are mindful of the limitations and that the data is not generalizable (Atkinson and Flint 2001) although our findings do point to significant commonalities within the data which reflect refugee histories and asylum and refugee policies.

As the research was with UK born adults, all the interviewers were carried out in English by the university based research team and were recorded, transcribed and anonymised. The interview data was coded thematically and analysed using NVivo. The rest of the paper explores the research findings.

\section{Types of school attended and parental strategies}

Our interviewees had spent all or most of their childhoods in London and so mainly had experience of schools within London although some had also attended school outside of London as well. The ages of our interviewees ranged from 18 to 36 (see Table 1) so their schooling had been within the predominately comprehensive system which, by the mid-1970s had been almost completely implemented. Moreover, all our interviewees had attended secondary schools after the 1988 Education Reform Act, which included the Local Management of Schools, the national curriculum, extensive testing and the principle of greater school choice within state provision though marketisation (Bloch, Neal and Solomos 2013; Kulz 2014). Finally, 'inclusive multicultural polices', a product of the Swann Report (1985) were already the norm and pre-dated our cohort's entry into the school system. However, policy and practice do not always correlate and choices, that depend on resources and local networks, means that many are excluded and social and geographical divisions within education have been maintained (Weekes-Bernard 2007).

This paper focuses mainly on secondary (11 years and older) education because interviewees had clearer recollections and it is the transition from primary to secondary where more choices are available and made. In England, the most common types of schools at secondary level are: community schools / comprehensive schools which are controlled by the local council and are secular; academies, run by a governing body and independent from the local council; grammar schools that almost always select pupils based on academic ability and require pupils to take an exam as part of the selection process and faith based schools. Only a small proportion of children nationally are educated at grammar schools. Since 1979 between 3 per cent and 5.2 per cent of secondary school aged children have attended grammar schools (Bolton 2016).

Among our interviewees there were clear patterns in relation to the types of secondary school attended as Figure 1 shows. With the exception of one interviewee of Vietnamese heritage who went to a grammar school in Kent - one of the few areas that had not gone fully comprehensive by the 1970s -everyone from Vietnamese and Kurdish background had been to comprehensive schools, which is in contrast to the Tamil heritage cohort.

Figure 1: Type of school attended by parent's country of origin Base number: 45 


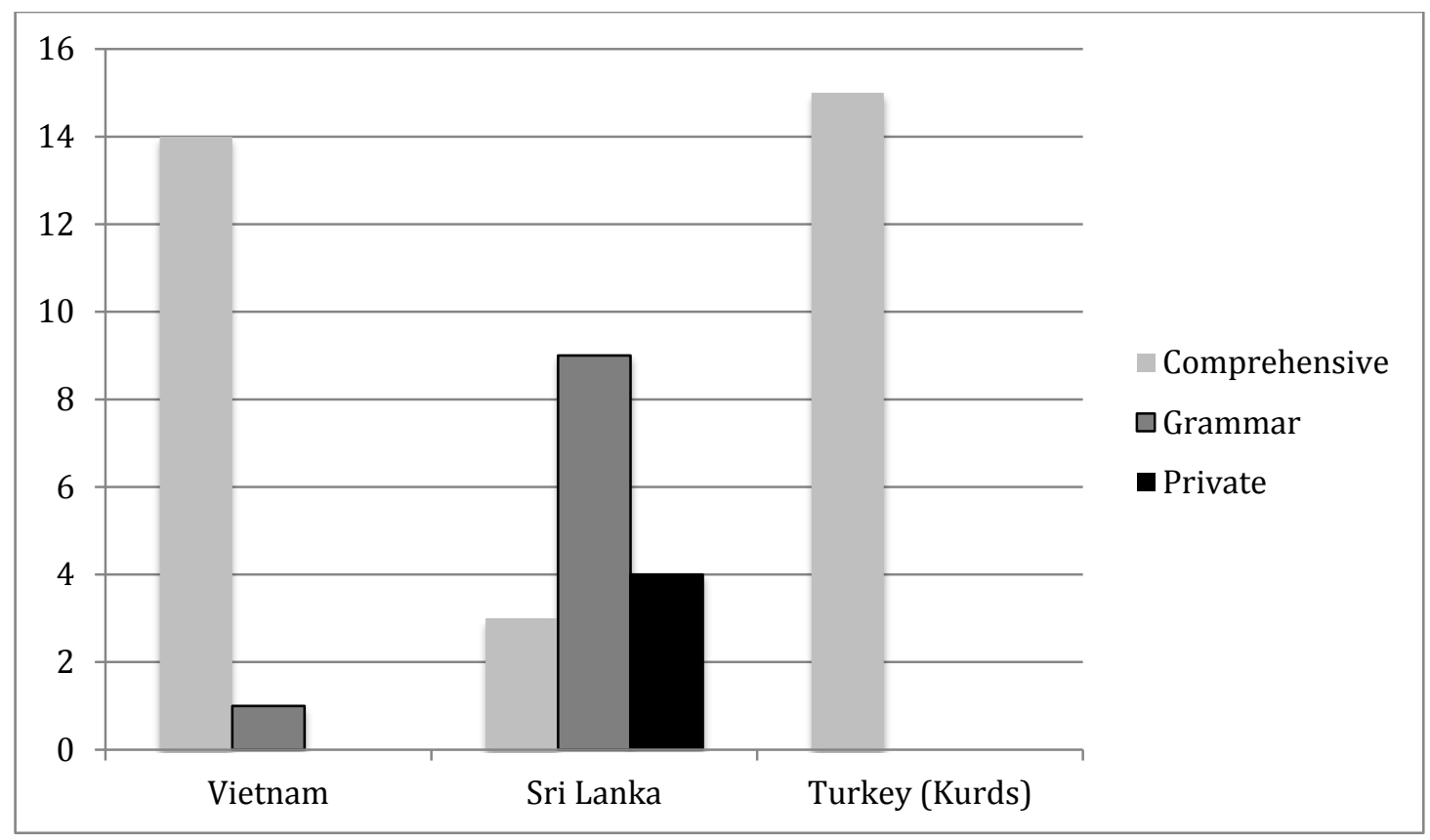

Figure 1 shows it was almost exclusively those from Tamil backgrounds who attended selective grammar schools. Their parents used resource rich social networks, English language and their education to find out about the best schools through word of mouth and by checking published school results, reports and prospectuses. Among the small number from Tamil backgrounds who attended comprehensive schools it was evident that their parents still made careful decisions about which particular comprehensive their children would attend.

The education strategies among those from Tamil backgrounds were carefully planned and this included tutoring for the selective schools. Krishnan a man from Tamil heritage explained how he went to the best school in the area, 'one where you're likely to do well', and how his education was also carefully investigated and strategised with his mother tutoring him for the grammar school tests. Anton grew up in East Ham, in east London, where there is a dense clustering of people from Sri Lankan backgrounds. In his interview he explained how everyone he knew had tutoring to get into the grammar school, describing information and strategies as 'going viral' in the local Tamil community. The local social networks did not exclude those with less education or fewer financial resources. Sharlini for instance went to the grammar school, which she said, 'my mum knew about it because of other Tamil people telling her about it'. Her father worked for a fast food chain while her mother cooked on a self-employed basis, had not completed primary school and did not speak English but was still able to use her networks with other Tamils as a source of information.

While the parents of those from Tamil backgrounds used their resources - both social and economic - to try and ensure that their children gained entry to the schools with the highest academic achievement, those from Kurdish and Vietnamese backgrounds usually went to what were assumed to be less desirable local schools in often deprived and under resourced inner city areas. The lack of choice or support available to their parents to overcome barriers and to make informed choices was prevalent in the narratives of those from Vietnamese and Kurdish backgrounds where families simply did not know what choices they had. According to Rojda, 
Where I lived we never knew about grammar schools because our parents never knew, they are still illiterate (Female, Kurdish background).

Moreover, among those from Kurdish and Vietnamese backgrounds it was evident that the co-ethnic networks they accessed lacked knowledge of the school system and the best schools and could therefore in some instances reproduce disadvantage as Rodja observed.

My university is a Russell Group one. All my friends at university went to grammar school and come from privileged backgrounds. I would never change my secondary school for anything but the resources and quality of education was made so you could get into labour jobs. It was like you are working class; you are not going to get anywhere (Female, Kurdish heritage).

While choice is the cornerstone of the education system, the reality is that choice depends on knowledge which some, such as Quan's family, were unable to access.

My parents had no idea about the system, it was just the closest ones to our house that was it...they didn't understand the world coming from another country to the UK (Quan, Male, Vietnamese heritage).

There were clear differences in relation to the schools attended and the access to information and resources needed to inform choices between the three groups. However, almost universal to the experiences of second generation were the orientation of parents to their children's education and the linkages of their aspirations and those of the second generation to refugee backgrounds, as we explore in the next section.

\section{Aspirations and attitudes to education; intersections with refugee backgrounds}

Almost everyone felt a strong parental orientation towards education, which they linked to their refugee backgrounds. Children were made aware of the need to make the most of the opportunities their parents had missed by the disruption of civil war and/or discrimination and in some cases gender norms. In the following quote Saama, who was a medical student, explains the inter-generational focus on education and the links between that and her father's own lost opportunities through his political activities and imprisonment in Sri Lanka.

...we were always told about the importance of education and how they missed out on an education, being refugees and victims of war...[my dad]... was involved heavily in the political side of things...He was caught and then put into prison for four years. And he's always said how he missed out on his education because of that (Female, Tamil heritage).

Some took on their parent's ambition as their own. The blocked opportunities of parents were transmitted between generations and became entwined with the hopes of the second generation. Rabithan had initially tried to go to medical school but did not obtain a place so did a first degree before converting to medicine. He provides an illustration of the blurring between his hopes, those of his father and his refugee background. 
I've always wanted to be a doctor. And when I didn't get in the first time round I was gutted, it destroyed me actually... It was my dad's dream in Sri Lanka [to be a doctor] but in Sri Lanka it's really really tough to do, especially for a Tamil growing up in a Sinhalese dominated country (Male, Tamil heritage).

Abi's father used his refugee background to encourage his teenage children to focus on their studies and resist other distractions but there was also an inter-generational transmission of displacement and the lack of belonging.

My dad will emphasise the importance of education... my dad will talk about our refugee background and emphasise this is not where we're from this is not our country and remember that (Female, Tamil heritage).

Not only was education a way of fulfilling the unrealised dreams of the refugee generation, it was also seen as the route to mobility, the way to regain lost status and a means for life-long security for their children. The transmission of past and current hardships as a way of securing a more stable and affluent future for children is not an unusual dimension of the inter-generational relationships between refugees and their children. Research with Vietnamese second generation in Norway highlighted the 'debt of gratitude' that children felt they owed their parents, which could be demonstrated through educational achievement (Fekjær and Leirvik 2011). Similarly, research focusing on genocide survivors makes links to the notion of intergenerational restitution among the genocide survivor generation and their children (Richter 2014). Children offer restitution to their parents while for children, as the objects of this restoration there was identification with their parent's ambition and the need to fulfil the role projected onto them. In the following quotes both Kim and Sharlini use the word 'proud' to convey their sense of the restorative part they played in their parent's losses and the ways in which it motivated them.

The more they talk about their lack of opportunities the more it pushes us to study and get a good job and stuff. Make them proud (Sharlini, Female, Tamil heritage).

...my mother and my grandparents always tell me these old stories of coming over, how different it was, and all the struggle, and I think it's my personal drive that I want to basically honour my parents because they have struggled, and they've been very much, how should I say, trying their best, to actually provide for me, so I feel it is my obligation to do well, to make them proud (Kim, Female, Vietnamese heritage).

Wanting to succeed is not just about making parents proud. For Rodja, ambition is based on a complex grouping of both pre and post exile experiences that she explains.

I come from a war zone. There are four things wrong for me from that place; I'm Kurdish, I'm Alevi, I'm a socialist and I'm female. It's a massive deal in Turkey, maybe not here. If they ask me why I'm in uni and why I want to become someone it's for two reasons; One, I want to become someone to prove something to myself. Two, for my family and for everything they have been though. The worst thing in the world is being stuck in a one bedroom house in Glasgow and hearing a phone call to my mum saying her dad died and not being able to go back because we didn't have visas, so my mum couldn't see her dad's grave (Female, Kurdish heritage). 
In the quote above, Rodja is also making reference to the impact of exile and the insecurity of immigration status on her family. Rodja's mother entered the UK using the passport of her uncle's wife and was in hiding on arrival. Entering the UK clandestinely with the help of smugglers or agents and with someone else's documents is not unusual among Kurds from Turkey given the immigration controls in place that restrict entry to the UK (Bloch and McKay 2016). Rodja was not alone in mentioning her family's irregular entry and the impact of this insecure status on children. It was clear that the image for Rodja, of her mother's loss was a powerful one and throughout her interview she makes references to her mother's experiences both before migration and in exile using these as a form of comparison and as a platform for her own ambitions. Rodja was born in Scotland and her family later moved to London to be near her uncle; she is one of a number of our interviewees who had moved one or more times during their childhoods, a pattern that linked to dispersal and to local authority asylum housing policies. In the next section we explore mobility and the ways in which it impacted on educational experiences.

\section{Refugee backgrounds: Dispersal, geographical mobility and school}

The impact of refugee backgrounds influenced a number of our participants' school trajectories especially the asylum process, resettlement and secondary migration. Earlier in the paper we explained that Vietnamese refugees had been part of a resettlement programme that included dispersal around the country and how many had subsequently migrated within the UK. This pattern of onward migration has been replicated among more recent arrivals, once refugee status is granted, for reasons that include proximity to co-ethnic community networks and to access the associated employment opportunities (Stewart and Shaffer 2015). There was also mobility due to local authority housing policies where inner London boroughs have paid outer London boroughs to house asylum seekers and refugees to ease housing shortages. As a consequence a number of our interviewees had experienced ruptures to their education through on-ward migration and local authority rehousing.

Many of those from Vietnamese backgrounds talked directly and spontaneously about dispersal (nine out of 15 interviewed). Sites of initial dispersal included Glasgow, Newcastle, Derby, Nottingham and Leeds and families had subsequently moved to London sometimes with the help of family members, networks and/or the assistance of NGOs. Tammi explained how her family were settled in Leeds and how, 'they were just plonked in the middle of nowhere, just all these little Vietnamese people in this one centre'. The Red Cross had helped her family and other Vietnamese families to move to London by,

...helping with the culture shock, putting them near each other after the dispersal policy the government had messed up (Tammi, Female, Vietnamese heritage).

Anne and Paul's parents also came to the UK as programme refugees having been resettled from camps in Hong Kong. Both families were dispersed to Scotland; Anne's family then moved directly to London while Paul's family moved to Manchester and then a few years later to London to enable his parents to find jobs in restaurants in China Town and to connect to wider family and social networks. In the following quote Paul recounts his first day at school in London and the alienation he felt. 
I remember the shock after my mum dropped me at school and I really didn't want to be there. Because I'd been living in Manchester I didn't know no one in this new place...it was really hard. So I remember trying to beg my mum not to leave me there. I can remember the day; I was crying my eyes out not wanting to be in school (Male, Vietnamese heritage).

Emily's narrative demonstrates the family mobility, which can be a condition of exile and refugee policy. Her oldest sister was born in Hong Kong, her second sister in Nottingham and she was born in North London, where her family lived on a council estate in a very ethnically mixed area. When Emily was nine, the family were moved out to Beckton in the London Borough of Newham in east London, which at that time was very desolate, with high rates of unemployment and little ethnic diversity. Having attended a very ethnically mixed primary school that was attentive to diversity and even offered Chinese classes, the secondary school ignored her background completely. She describes the move in the following way:

...it was one of the biggest changes of my life. Moving into an area that was predominantly white...Beckton, near the docklands. It's a new area so it was previously marshland. So a lot of new families moved to that area [it was] predominantly a white area for many generations and then I went to a community secondary school. I struggled at school I was a minority amongst minorities and it made things very confusing for me growing up (Female, Vietnamese heritage).

Rodja's education was also disrupted; her family moved from Glasgow to London to be near her uncle but the change was a positive one for her because she moved to an ethnically mixed environment.

Well when I was born we lived as refugees in Glasgow because at the time Glasgow was where lots of [refugee] families went...Glasgow, even now, has few ethnic minorities; mainly white, Scottish. Since I lived in Scotland then came here [London] at 8 the first few years of nursery and primary were in Scotland. I remember going to a school full of blonde, blue eye kids. I remember my mum brought me out of a dance class because I was the only brunette, never mind only dark skinned person. She didn't want me to experience any discrimination. When I moved here I lived in poor area of east London...Before that we were migrating all over the place, Tottenham, Green Park Lane. I lived on top of a kebab shop... When we moved here I remember a lot of other families moved here. A lot of Kurdish people were in London...I went to a local primary school and I went to a local secondary and then I went to a really ghetto 6th form. So I grew up within communities of integrated ethnic minorities. I've never experienced any discrimination; I adopted their culture growing up...Africans, Asian, all sorts really. In Scotland I was in an ethnic minority but in a lot of schools in London, the white British are in the minority.

Rodja is equating the diversity of her London schools with an absence of discrimination. As our study was focussed on those who spent all or part of their childhoods in London, for the most part they were in ethnically diverse areas and nearly everyone (38 out of 45) described their schools as ethnically mixed. This diversity was often seen as positive and inclusive as Ezgi explains. 
Hackney, it's like a safe haven because everyone else around me was from a different place (Female, Kurdish heritage).

The minority who had attended schools with mostly white pupils had either moved outside of London for short periods of time or been housed in parts of London that were less diverse, such as Emily's experience in Beckton. Rachel provides an extreme case. She had been to eight different schools some in London some outside of London, including a Catholic secondary school outside of London, where many of the other pupils were from white Irish backgrounds. She describes her experiences as follows:

...it did feel like an issue, me being brown or whatever...I've got a twin brother...he got bullied a lot...they'd be implying that we were Muslim, that we weren't actually Catholic, things like that. It felt uncomfortable (Female, Tamil heritage).

Reflecting on her varied school experiences Rachel concluded that she preferred the school that 'was really mixed and multicultural'. Where racism was experienced it was not generally specific to their refugee backgrounds but involved more generalised forms of racism and racist bullying and included racist name-calling. Sophia who was from a Vietnamese background said 'I obviously got name-calling, you know Ching Chong'. Others were bullied for having a 'foreign' sounding name as Helat recounts.

I was bullied from year seven because of my name and it happens to a lot of people... if their name isn't English they'll still laugh at your name... It really does get to you (Male, Kurdish heritage).

Being within an ethnically mixed school did not always protect from these kinds of racism although for those within inner city ethnically diverse schools, the diversity was seen as positive and enhancing but could also mask their own differences. Refugee policy clearly impacts on these experiences, with government enforced dispersal to areas that were often economically deprived, without a history of diversity or co-ethnic networks which could lead to isolation and poor employment opportunities for many refugee families (Sales 2007). The impact of the policy context on mobility and the links between mobility and school experiences has been explored in this section. In the next section we explore parental involvement and school support.

\section{Parental involvement and school support}

The importance of parental involvement in the educational outcomes of children is widely accepted (Epstein 2013). Involvement may be within the home but schools also have a role in facilitating engagement, with all parents, not just those that are easy to reach (Hornby and Lafaele 2011; Epstein 2013). In this section we explore perceptions of schools and their institutional engagement with both parents and the backgrounds of their refugee heritage pupils. As our focus is on the perspectives of the second generation it could be that they were unaware of some of the work schools did with parents. However the view of those interviewed was that, where language, lack of knowledge about the system and long and unsocial working hours prevented meaningful parental engagement, little was done by schools to alleviate the barriers. Those from Tamil backgrounds rarely talked about obstacles, but instead the 
numerous ways in which their parents supported their education through help at home, paying for tutoring and attending parent evenings. For other parents, and most often when language represented a barrier, little or nothing was done to empower parents. Instead, schools relied on either the pupil or older siblings to interpret including at parent evening. In the following quote Gilay talks about how the combination of long working hours and language were barriers to parental involvement.

I would always bring my mum to parents evening... My dad couldn't come because he worked all the time [as a taxi driver] so he didn't find the time...usually I'd translate for my mum (Gilay, Female, Kurdish heritage).

At Gilay's secondary school there was a large number of Somali heritage children and the school was quite responsive to the linguistic needs of this group of parents in contrast to her own parents. However, this was unusual and the norm was for children or older siblings to act as interpreters. When acting as a translator, some of our interviewees talked about fabricating what was said to make it sound positive.

Anytime the teacher would try and say something bad I'd just translate it to make it sound good. She [mother] can't work it out (Quan, Male, Vietnamese heritage).

These barriers also extended into parental involvement with school communities as Helat explains when he compares his situation with that of his peer group.

...my parents, they've always wanted me to study. They've always cared. But they can't do nothing about it cos they haven't got English. Growing up you had people's parents involved within the school life, they would come in to the school, talk to the teachers, helping out, all these things. But my parents were never able to do that, so I never felt like they were actually involved. All they would say was 'study study study' but they never actually physically got involved (Male, Kurdish heritage).

The lack of support for parental engagement also extended to a lack of engagement with the backgrounds of children. The view of our interviewees was that where schools were ethnically diverse, they were aware of migrant backgrounds but generally unaware of anything more specific. Migrant families were placed in a homogenous group as Leyla, who went to an ethnically mixed inner city comprehensive school explained.

Maybe people knew that we weren't English but I don't think it was a big deal...just like one more child to the list (Female, Kurdish heritage).

Sarah had a similar experience noting the school's lack of engagement in the specifics of backgrounds saying that 'no one really asked' (Female, Vietnamese heritage). In the case of Kurds, who often identified as Kurdish, but were perceived as Turkish by school structures this could be an issue. In the following quote Zelat describes how she and her friends made an effort to challenge assumptions, and highlight their backgrounds, when starting secondary school.

Well when we started, when you write your ethnicity on the form there wasn't a Kurdish option, only Turkish so we all wrote Kurdish in 'other'. And when 
other students would see this they'd ask what Kurdish was, they didn't know. There were a few Turkish teachers who would have been aware but the other teachers didn't really seem to know.

In fact awareness of the specificities of refugee backgrounds, possible experiences and any interventions that may help seemed to be ignored with the exception of two interviewees where problems either at school or at home had resulted in greater engagement of teachers with parents. Taylan, a young man of Kurdish heritage, had been excluded and expelled from multiple schools and his dad was called in to speak to the school on these occasions while Janith, a man of Tamil heritage, experienced problems which led to him leaving the family home and so the school became aware of his background. These are two examples that stand out because of clear problems, rather than a sustained or clear school strategy towards the children of refugees.

In the few instances where schools were aware of refugee backgrounds there was a sense of discomfort and it being 'a bit awkward' as Tammi explained.

Maybe they were aware, but there was nothing said about it. I think it was a bit awkward...they should have assumed coming from a refugee background the children would need more support but it never was discussed with them (Female, Vietnamese heritage).

It seemed that schools did little to find out about their pupils backgrounds or to support their parents to actively engage, unless there was a problem. The failure to provide an interpreter can also impact on the parental-child relationship by redefining power and control. Children in this setting become both the object of discussion and the transmitter of that discussion subjecting them and their parents to the crossing of inter-generational borders and where parents can be infantalised by their dependency on their children (Orellana, 2009) who were not always honest with their translations further impeding meaningful participation in their child's education.

\section{Conclusion}

In this paper we have highlighted how refugee backgrounds can and do shape educational experiences. The second generation felt that their parent's experiences both pre and post exile - impacted on their attitudes to education and on occasion was strongly transmitted inter-generationally to their children. Also significant however, are factors that relate to structural divisions that can and do reproduce class and race based educational inequalities. Diversity is inherent in the category refugee and the importance of understanding and responding to heterogeneous pre-migration and post-migration experiences of individuals and significantly family groupings is clear in this and other research (Rutter 2006). However this paper has shown that educational policies are not sensitive to or orientated towards the variable needs of second generation from refugee backgrounds.

In this research the advantages and disadvantages associated with different social and economic resources were evident. This meant that the experiences of those from Tamil backgrounds, who for the most part attended selective grammar schools, contrasted with the experiences of those from Vietnamese and Kurdish backgrounds who had fewer resources. The idea of 'choice' in education is really just a choice for the already empowered and, as Vincent et al. (2012) argue, it is not simply about resources is it also about reproduction of certain behaviour mediated by structure. 
Moreover, there was an unexpected lack of support from schools who did not actively facilitate partnerships with parents or take steps to alleviate structural barriers and facilitate involvement through small but potentially empowering interventions such as offering interpreters at parent teacher evenings.

Regardless of the obstacles experienced by some parents from refugee backgrounds they were, almost without exception, orientated towards the education of their children. Although parents from Vietnamese and Kurdish backgrounds were for the most part less able than parents from Tamil backgrounds to help with homework, to provide tutors or to engage with school selection and school communities it did not make them less aspirational for their children. Parents wanted their children to have the security that they themselves lacked, to take advantage of the opportunities that were not afforded to them and to be empowered in ways that they, as the refugee generation were not. These aspirations were transmitted to the second generation who in some instances saw their role as one of restitution.

While the barriers to active parental participation and choice interact with structural divisions based on race and class, the findings have pointed to the ways in which the specificities of refugee and asylum policy can exacerbate these divisions. In the UK context the geographical mobility associated with dispersal and housing policy impacted on education either through a disrupted education entailing multiple schools or for some spending time in schools that lacked ethnic diversity. Dispersal is not unique to the UK and is used widely in Europe (OECD 2016) so a similar pattern of educational disruption is likely. Dispersal outside of the major urban centres can also result in children being placed in less ethnically diverse schools, which can result in more racism and discrimination, a pattern identified in the UK and elsewhere in Europe (Bloch et al. 2015). However, it is not just asylum policy that can impact on education; the wider integration context and institutional variations within educational provision also shape educational outcomes and these vary in different geographical contexts (Crul, Schneider and Lelie 2012). Our findings point to a significant relationship between asylum policy and second generation educational experiences, a nexus which was perhaps previously unexpected. As political discourse continues to frame the 'asylum seeker' and refugee as a danger or 'problem' to the nation, our research has demonstrated the impact such hostile policies have not just on the target group, but also on the British born second generation, a diverse cohort that has been largely over-looked.

The lack of engagement with the backgrounds of pupils with refugee parents coupled with dispersal to areas outside of urban centres makes it likely that the experiences of the second generation will continue to be inflected by racism and limited support for families. Such experiences will add to the already insecure situation some families find themselves in where refugee status is no longer permanent, where policies continue to restrict and the media and politicians continue to present negative views of refugees and asylum seekers. It is important to address the ways in which race and class continue to operate within schools but added to that, the complexities of coming from a refugee background should not be ignored.

\section{References}


Alexander, Claire, Debbie Weekes-Bernard, and Joya Chatterji, eds. 2015. History Lessons: Teaching Diversity In and Through the History National Curriculum. London: Runnymede Trust.

Anderson, B. and R. Williamson. (2004) Diversity in the Classroom: Discussion Paper. Oxford: Centre on Migration, Policy and Society, University of Oxford.

Arnot, M. and H. Pinson. 2005. The Education of Asylum-Seeker and refugee Children: A Study of LEA and School Values, Policies and Practices. Cambridge: Faculty of Education, University of Cambridge.

Atkinson, R. and J. Flint. 2001 "Accessing Hidden and Hard-to-reach Populations: Snowball Research Strategies." Social Research Update 33 University of Surrey, http:// www.soc.surrey.ac.uk/sru/SRU33.html.

Berry, Mike, Inaki Garcia-Blanco, and Kerry Moore. 2015. Press Coverage of the Refugee and Migrant Crisis in the EU: A Content Analysis of Five European Countries. UNHCR, http://www.unhcr.org/56bb369c9.html

Bloch, A. 2002. The Migration and Settlement of Refugees in Britain. Basingstoke: Palgrave Macmillan.

Bloch, Alice, Sarah Neal, and John Solomos. 2013. Race, Multiculture and Social Policy. Basingstoke: Palgrave Macmillan.

Bloch, Alice, Milena Chimienti, Anne-Laure Counilh, Shirin Hirsch, Giovanna Tattolo, Laurence Ossipow, and Catherine Wihtol de Wenden. 2015. Eds. The children of refugees in Europe: aspirations, social and economic lives, identity and transnational linkages. Country reports-Working paper. Geneva: Swiss Network for International Studies. http://www.snis.ch/project_children-refugees-europeaspirations-social-and-economic-lives-identity-and-transnational

Bloch, A. and S. McKay. 2016. Undocumented Migrants in a Global City. Bristol: Policy Press.

Bolton, P. 2016. Grammar School Statistics. House of Commons Library Briefing Paper, Number 1398, London: House of Commons.

Byrne, B. and C. De Tona. 2012. "Trying to Find the Extra Choices: Migrant Parents and Secondary School Choice in Greater Manchester." British Journal of Sociology of Education 33 (1): 21-39.

Cantle, T. 2001. Community Cohesion: A Report on the Independent Review. London: Home Office.

Cowley-Sathiakumar, S. R. 2008. The Sri Lankan Tamils: A Comparative Analysis of the Experiences of the Second Generation in the UK and Sri Lanka. PhD thesis: University of Leeds.

Crozier, G. and J. Davies. 2007. "Hard to Reach Parents or Hard to Reach Schools? A Discussion of Home-School Relations, with Particular Reference to Bangladeshi and 
Pakistani Parents.” British Educational Research Journal 33 (3): 295-313

Crul, Maurice, Jens Schneider, and Frans Lelie, eds. 2012. The European Second Generation Compared: Does the Integration Context Matter? IMISCOE Research: Amsterdam University Press.

Department for Education. 2014. GCSE and Equivalent Attainment by Pupil Characteristics in England, 2012/13. London: Department for Education.

Demir, I. 2012. "Battling with Memleket in London: The Kurdish Diaspora's Engagement with Turkey." Journal of Ethnic and Migration Studies 38 (5): 815-831.

Dustmann, C. and N. Theodoropoulos. (2010). "Ethnic minority immigrants and their children in Britain." Oxford Economic Papers 62 (2): 209-233.

Dustmann, Christian, Tommaso Frattini, and Gianandrea Lanzara. 2012. "Educational achievement of second-generation immigrants: an international comparison." Economic Policy 27 (69): 143-185.

Epstein, J. 2013. "Ready or not? Preparing future educators for school, family, and community partnerships." Teaching Education 24 (2): 115-118.

Fekjær, S. and M. Leirvik. 2011. "Silent Gratitude: Education among SecondGeneration Vietnamese in Norway." Journal of Ethnic and Migration Studies 37 (1): 117-134.

Gardner, G. 2001. "Unreliable memories and other contingencies: problems with biographical knowledge." Qualitative Research 1 (2): 185-204.

Grillo, R. 2005. "'Saltdean Can't Cope': Protests Against Asylum-Seekers in an English Seaside Suburb.” Ethnic and Racial Studies 28 (2): 235-260.

Healey, R. 2010. Refugee Employment Experiences: The Case of Tamil Refugees in the UK. PhD Executive Summary: University of Chester.

Holgate, Jane, Janroj Keles, Anna Pollert, and Leena Kumarapan. 2012. "Workplace Problems Among Kurdish Workers in London: Experiences of an 'Invisible' Community and the Role of Community Organisations as Support Networks." Journal of Ethnic and Migration Studies 38 (4): 595-612.

Hornby, G. and R. Lafaele. 2011. "Barriers to parental involvement in education: an explanatory model." Educational Review 63 (1): 37-52.

Jones, P. 1983. "Vietnamese in the UK: The Reception Programme." New Community 10 (3): 444-453.

Kulz, C. 2014. "“Structure liberates?': Mixing for mobility and the cultural transformation of 'urban children' in a London academy." Ethnic and Racial Studies 37 (4): 685-701. 
Kushner, T. and K. Knox. 1999. Refugees in an Age of Genocide: Global, National and Local Perspectives During the Twentieth Century. Abingdon: Frank Cass.

Lewis, Hannah, Peter Dwyer, Stuart Hodkinson, and Louise Waite. 2014. Forced Labour, Exploitation and Asylum. Bristol: Policy Press.

Maylor, U. 2015. "Challenging Cultures in Initial Teacher Education." In The Runnymede School Report: Race, Education and Inequality in Contemporary Britain, edited by Alexander, Claire, Debbie Weekes-Bernard, and Jason Arday, 27-31. London: Runnymede Trust.

OECD. 2016 Making Integration Work: Refugees and others in need of protection. Paris: OECD Publishing (Organization for Economic Cooperation and Development).

Orellana, M.F. 2009. Translating Childhoods: Immigrant youth, language and culture. New Jersey: Rutgers University Press.

Portes, Alejandro, Patricia Fernández-Kelly, and William Haller. 2009. "The Adaptation of the Immigrant Second Generation in America: A Theoretical Overview and Recent Evidence." Journal of Ethnic and Migration Studies, 35 (7): 1077-1104.

Reynolds, G. 2008. The Impacts and Experiences of Migrant Children in UK Secondary Schools. Sussex Working Papers in Migration Research 47: University of Sussex.

Richter, J. 2014. "Intergenerational Layers of Silence: How the Concealed or the Outspoken Remain Undiscussable" paper presented at Psychoanalysis and Politics, Central University, Budapest.

Robinson, V. and S. Hale. 1989. The Geography of Vietnamese Secondary Migration in the UK. Warwick: ESRC Centre for Research in Ethnic Relations.

Rollock, Nicola, David Gillborn, Carol Vincent, and Stephen Ball. 2014. The Colour of Class: The Educational Strategies of the Black Middle Classes. London and New York: Routledge.

Rumbaut, R. G. 2012. 'Generation 1.5, Educational Experiences of' in Encyclopedia of Diversity in Education, edited by James Banks, 982, Thousand Oaks, CA: Sage Publications. https://papers.ssrn.com/sol3/papers.cfm?abstract_id=2182167

Rutter, J. 2006. Refugee Children in the UK. Maidenhead: Open University Press.

Sales, R. 2007. Understanding Immigration and Refugee Policy; Contradictions and Continuities. Bristol: Policy Press.

Sharma, V. 2009. "Inherited Memories: Second generation partition narratives from Punjabi families in Delhi and Lahore." Cultural and Social History 6 (4): 411-428

Smart, C. 2011. "Families, secrets and memories.” Sociology 45 (4) 539-553 
Somerset, F. 1983. "Vietnamese Refugees in Britain: Resettlement Experiences." New Community 10: 454- 63.

Spicer, N. 2008. "Places of Exclusion and Inclusion: Asylum-Seeker and Refugee Experiences of Neighbourhoods in the UK." Journal of Ethnic and Migration Studies 34 (3): 491-510.

Stewart, E. and M. Shaffner. 2015. Moving on? Dispersal Policy, Onward Migration and Integration of Refugees in the UK: Final Report. Glasgow: University of Strathclyde.

Strand, S. 2014. "Ethnicity, Gender, Social Class and Achievement Gaps at Age 16: Intersectionality and 'getting it' for the White Working Class." Research Papers in Education 29 (2): 31-171.

Swann Report. 1985. Education for All: Report into the Committee of Inquiry into the Education of Children from Minority Ethnic Groups. London: Her Majesty's Stationary Office.

Taylor, S. and R.K. Sidhu. 2012 "Supporting Refugee Students in Schools: What Constitutes Inclusive Education?" International Journal of Inclusive Education 16 (1): $139-56$.

Tomlinson, S. 2008. Race and Education: Policy and Politics in Britain. Maidenhead: McGraw-Hill Open University Press.

Troyna, B. and B. Carrington. 1990. Education, Racism and Reform. London: Routledge.

Vincent, Carol, Nicola Rollock, Stephen Ball, and David Gillborn. 2012. "Being Strategic, Being Watchful, Being Determined: Black Middle-Class Parents and Schooling." British Journal of Sociology of Education 33 (3): 337-354.

Weekes-Bernard, D. 2007. School Choice and Ethnic Segregation: Educational Decision Making among Black and Minority Ethnic Parents. London: Runnymede.

Funding: This work was supported by the Swiss Network for International Studies, grant number 13-6401.

Acknowledgements: Thanks to our colleagues and collaborators on the project, Milena Chimienti, Anne-Laure Counilh and Laurence Ossipow from the University of Applied Sciences and Arts of Western Switzerland and Giovanna Tattolo and Catherine Wihtol de Wenden from Centre d'études et de recherches internationales at Sciences Po Paris. 